\title{
myo-Inositol: A Newly Identified Nonnitrogenous Osmoregulatory Molecule in Mammalian Brain
}

\author{
JEAN HOLOWACH THURSTON, WILLIAM R. SHERMAN, RICHARD E. HAUHART, AND \\ ROBERT F. KLOEPPER \\ Departments of Pediatrics [J. H. T., R. E. H.] and Psychiatry [W. R. S., R. F. K.], Washington University School \\ of Medicine, St. Louis Children's Hospital, St. Louis, Missouri 63110
}

\begin{abstract}
Sugar alcohols have been found to play an important osmoregulatory role both in unicellular organisms and, more recently, in multicellular organisms, including mammals. This study shows that myo-inositol accumulates in the brains of chronically hypernatremic mice, as had been earlier found in rats, and demonstrates for the first time a profound decrease of myo-inositol in the brains of chronically hyponatremic mice. Together with decreases in better known cerebral osmoles (amino acids and related nitrogenous compounds), the decrease in myo-inositol apparently allows the brain to balance its intracellular osmolality with that of the plasma, permitting a normal brain water content (no edema) despite profound hyponatremia. (Pediatr Res 26:482-485, 1989)
\end{abstract}

Cellular adaptation to osmotic stress is a vital biologic process that protects organisms from the possibly lethal effects of dehydration and shrinkage, or edema and swelling of cells. In 1955 McDowell et al. (1) described the generation of unidentified ("idiogenic") osmotically active particles other than electrolytes in mammalian tissues in response to treatment with hyperosmolar solutions. Since then a large number of studies have appeared concerning the cellular adaptation of different species to osmotic stress. Duchateau et al. (2) were the first to show that loss or gain of free tissue amino acids played a prominent role in the adaptation of invertebrates to extremes of environmental salinities. The role of amino acids and related compounds in adaptation to salinity change has since been extended to bacteria (3), plants (4, 5), amphibians (6), and mammals (7-11). Not all amino acids contribute equally to cellular osmoregulation. For example, on a molar basis the greatest concentration change during salinity stress was in alanine in bivalve molluscs (12), glycine in lobsters (13), glutamate in toad (14), and taurine in mouse brain $(9,10)$. Also, not all osmoregulators are of nitrogenous origin. In osmophilic yeasts the predominant osmoregulatory molecule is arabitol (15), in green algae, it is glycerol (16). Recently a significant role of sugar alcohols in osmoregulation in higher species has been recognized. Pinitol and myo-inositol have been found to accumulate in drought-adapted varieties of maritime pine during water stress (17). Bagnasco et al. (18) found increased levels of myo-inositol and sorbitol in rat and rabbit renal medullas during antidiuresis. Of especial interest to us, because of the important role of myo-inositol and the phosphoinositides in neural transmission, was the finding of Lohr et al.

Received May 19, 1989; accepted July 14, 1989. Correspondence Jean Holowach Thurston, M.D., Department of Pediatrics, St. Louis Children's Hospital, 400 South Kingshighway, St. Louis, MO 63110.

Supported in part by NIH Grants to J. H. T.: NS06163, NS 15660 , the Abbott Laboratories, Chicago, and the Allen P. and Josephine B. Green Foundation, Mexico, MO, and by NIH Grants to W. R. S.: NS05159, RR00954, and AM20579.
(19) that myo-inositol levels are increased in the brains of chronically hypernatremic rats. This was the first report citing an increase in inositol levels in brain and raises the important question of whether that change is reflected in the inositolcontaining lipids and in their function.

We have earlier reported on the effects of chronic hyper- and hyponatremia and the effect that rapid restoration of plasma $\mathrm{Na}^{+}$ levels to normal has on brain water, electrolyte, carbohydrate, energy and amino acid metabolism in young mice $(10,11)$. It was thus of interest to confirm the findings of Lohr et al. (19) in the chronic hypernatremic state and to examine the effect of chronic hyponatremia, and rapid correction, on brain myoinositol levels.

\section{MATERIALS AND METHODS}

Preparation of animals. Litters of normal 19- to 29-d-old Swiss Webster mice were used because of our clinical and research interest. In each experiment, control and experimental animals were weight-matched littermates.

Chronic hypernatremia and rehydration. Hypernatremia was produced by water deprivation and intraperitoneal injections of $1 \mathrm{M} \mathrm{NaCl}, 20 \mathrm{~mL} / \mathrm{kg}$, once or twice daily (seven doses total) for $4 \mathrm{~d}$; laboratory food was allowed ad libitum. Control littermates were allowed water and food and received an equivalent volume and number of injections of sterile $0.9 \% \mathrm{NaCl}$. On the fourth day, $2 \mathrm{~h}$ after the last injection, controls and one-half of the experimental animals were killed by decapitation. The remaining experimental mice were rehydrated over the next $4 \mathrm{~h}$ by three subcutaneous injections of $2.5 \%$ dextrose in water, $100 \mathrm{~mL} / \mathrm{kg}$ each dose, given at 80 -min intervals. Animals were decapitated 80 min after the last injection of the glucose solution.

Chronic hyponatremia and correction with saline. Chronic hyponatremia was induced in fasted and thirsted mice by intraperitoneal injection of $50 \mathrm{~mL} / \mathrm{kg}$ of $2.5 \%$ dextrose in $\mathrm{H}_{2} \mathrm{O}$ and subcutaneous injection of $5 \mathrm{U} / \mathrm{kg}$ of vasopressin tannate (Pitres$\mathrm{sin}$ ) in peanut oil once daily for $3 \mathrm{~d}$. There were two groups of normonatremic controls. One group was allowed food and water ad libitum. The second group was fasted and thirsted for $3 \mathrm{~d}$. Both groups received daily injections of $0.9 \% \mathrm{NaCl}$, intraperitoneally and subcutaneously, equal in volume to the $2.5 \%$ dextrose in $\mathrm{H}_{2} \mathrm{O}$ or vasopressin tannate given the hyponatremic animals (see above). At $0800 \mathrm{~h}$ on the fourth day, blood was collected from the snipped tail of some of the experimental mice for plasma $\mathrm{Na}^{+}$levels, after which the animals received one intraperitoneal injection of $1 \mathrm{M} \mathrm{NaCl}, 20 \mathrm{~mL} / \mathrm{kg}$, followed by two subcutaneous injections of $0.9 \% \mathrm{NaCl}$ (one at $1100 \mathrm{~h}$, the other at $1500 \mathrm{~h}), 30 \mathrm{~mL} / \mathrm{kg}$ each time. Animals were killed at $1700 \mathrm{~h}$, $9 \mathrm{~h}$ after the onset of treatment. Both groups of controls and the remaining untreated hyponatremic mice were decapitated in the afternoon of the fourth day. At decapitation the head was allowed to drop directly into liquid $\mathrm{N}_{2}$ with rapid stirring. Blood was 
collected from the severed neck vessels in heparinized microcapillary tubes (Caraway, American Hospital Supply Corp., McGaw Park, IL). Frozen heads were stored at $-80^{\circ} \mathrm{C}$ until the time of dissection and preparation of tissue extracts.

Preparation of plasma and brain. Blood was centrifuged promptly at $4^{\circ} \mathrm{C}$. Fresh plasma was used for electrolyte determinations. Frozen brain anterior to the posterior colliculi was dissected free of meninges and visible blood vessels in a cryostat at $-35^{\circ} \mathrm{C}$. The brains were powdered and weighed in a cold room at $-22^{\circ} \mathrm{C}$ and perchloric acid extracts were prepared at $4^{\circ} \mathrm{C}(20)$. The extracts were stored at $-80^{\circ} \mathrm{C}$ until the time of the assay.

Analytical methods. The $\mathrm{Na}^{+}$concentration in fresh plasma was determined in a flame photometer. myo-Inositol levels were measured as follows: $25-\mu \mathrm{L}$ aliquots of brain perchlorate extracts were lyophilized and treated with $100 \mu \mathrm{L}$ of dry pyridine:bis(trimethylsilyl)trifluoroacetamide (Regis Chemical Co., Morton Grove, IL) $1: 1$ (v:v) containing 50 pmol of $\left[{ }^{2} \mathrm{H}_{6}\right]$ myoinositol (MSD Isotopes, Montreal, Canada) as internal standard. After $24 \mathrm{~h} 1-\mu \mathrm{L}$ aliquots were analyzed on a Hewlett-Packard model 5970 gas chromatograph/mass spectrometer (HewlettPackard Co., Palo Alto, CA) using fragment ions $\mathrm{m} / \mathrm{z} 318$ for the endogenous myo-inositol and $\mathrm{m} / \mathrm{z} 321$ for the internal standard. Chromatography was on a 15 meter DB-17 column (J \& W Scientific, Folsom, CA) at $190^{\circ} \mathrm{C}$ using a split ratio of $10: 1$.

Statistical analysis. The statistical significance of the difference between the mean values of the findings in two groups of mice was determined by Student's $t$ test. When findings from three groups of mice were compared, statistical significance was first determined by a one-way analysis of variance followed by the HSD method of Tukey (21) to identify statistically significant differences between specific pairs of means.

\section{RESULTS}

The myo-inositol level in the brains of three different litters of normal 19- to 29-d-old mice (Tables 1-3) was similar to that reported by Stewart et al. (22) for normal adult rat brain. In adult rats Lohr et al. (19) found brain myo-inositol levels that were twice as high; we have no explanation for this discrepancy, however other laboratories have reported rat brain inositol levels similar to ours. For example Palmano et al. (23), using gas chromatography, as did Lohr et al. (19), reported control rat brain myo-inositol levels to be $6.62 \pm 0.96 \mathrm{mmol} / \mathrm{kg}$ wet wt ( $n$ =14) and MacGregor and Matschinsky (24), using an enzymatic fluorometric assay, reported rat brain myo-inositol levels to be $5.8 \pm 0.2 \mathrm{mmol} / \mathrm{kg}$ wet wt $(n=6)$.

Chronic water deprivation and salt loading of young mice induced a $43 \%$ increase in the brain myo-inositol concentration (Table 1). This increase was roughly equal to that found in chronically hypernatremic adult rats (19) and was quantitatively similar to the adaptive increases in levels of amino acids in these same animals (10). Rapid rehydration of the hypernatremic mice returned the plasma $\mathrm{Na}^{+}$concentration to normal but had no effect on the elevated brain myo-inositol content. The total sum of the measured cerebral amino acids was also still significantly higher after treatment than in the brains of normonatremic controls (10).

Inasmuch as the animal model of chronic hyponatremia necessitated withdrawal of food and water throughout the experimental interval it was important to examine the effect of these restrictions in normonatremic littermates (Table 2 ). The stringent experimental conditions induced a $4 \%$ increase in the plasma $\mathrm{Na}^{+}$concentration (probably a reflection of dehydration). Despite a wt loss of $26 \%$ (equal to that of the hyponatremic mice) there was no change in the brain myo-inositol concentration. In the brains of chronically hyponatremic mice the myoinositol concentration fell $88 \%$ (Table 3 ). By comparison levels of amino acids in these brains decreased 35 to $67 \%$ (11). Rapid elevation of the depressed plasma $\mathrm{Na}^{+}$level to normal with saline did not increase the brain myo-inositol content significantly and
Table 1. Effect of chronic hypernatremia and rapid correction on plasma $\mathrm{Na}^{+}$and brain myo-inositol levels in young mice $(\text { mean } \pm S E)^{*}$

\begin{tabular}{|c|c|c|c|}
\hline \multirow[b]{2}{*}{ Measurement } & \multirow[b]{2}{*}{$\begin{array}{l}\text { Control } \\
(n=6)\end{array}$} & \multicolumn{2}{|c|}{ Chronic hypernatremia } \\
\hline & & $\begin{array}{l}\text { Untreated } \\
(n=9)\end{array}$ & $\begin{array}{c}\text { Rapid } \\
\text { correction } \\
(n=4)\end{array}$ \\
\hline Plasma $\mathrm{Na}^{+}(\mathrm{mEq} / \mathrm{L})$ & 148 & 191 & 151 \\
\hline $\begin{array}{l}\text { Brain myo-inositol } \\
(\mathrm{mmol} / \mathrm{kg})\end{array}$ & $4.84 \pm 0.46$ & $6.91 \pm 0.24 \dagger$ & $6.07 \pm 0.32 \dagger$ \\
\hline
\end{tabular}

* Treatment of animals (number in parentheses) and other procedures are given in "Materials and Methods." Plasma $\mathrm{Na}^{+}$levels are taken from Reference 10.

$\dagger p<0.01$ versus control.

Table 2. Effect of chronic fasting and thirsting on plasma $\mathrm{Na}^{+}$ and brain myo-inositol levels in young normonatremic mice $(\text { mean } \pm S E)^{*}$

\begin{tabular}{lcc}
\hline \multicolumn{1}{c}{ Measurement } & $\begin{array}{c}\text { Fed controls } \\
(n=4)\end{array}$ & $\begin{array}{c}\text { Fasted and thirsted controls } \\
(n=6)\end{array}$ \\
\hline $\begin{array}{l}\text { Plasma Na }{ }^{+}(\mathrm{mEq} / \mathrm{L}) \\
\begin{array}{c}\text { Brain myo-inositol } \\
(\mathrm{mmol} / \mathrm{kg})\end{array}\end{array}$ & 142 & 148 \\
& $5.31 \pm 0.30$ & $4.46 \pm 0.54$ \\
\hline
\end{tabular}

* Preparation of animals (number in parentheses) and other procedures are given in "Materials and Methods." Plasma $\mathrm{Na}^{+}$levels are from Reference 11 .

Table 3. Effect of chronic hyponatremia and rapid correction on plasma $\mathrm{Na}^{+}$and brain myo-inositol levels in young mice $(\text { mean } \pm S E)^{*}$

\begin{tabular}{lccc}
\hline & & \multicolumn{2}{c}{ Chronic hyponatremia } \\
\cline { 3 - 4 } & $\begin{array}{c}\text { Fasted and } \\
\text { thirsted controls } \\
(n=6)\end{array}$ & $\begin{array}{c}\text { Untreated } \\
(n=10)\end{array}$ & $\begin{array}{c}\text { Rapid } \\
\text { correction } \\
(n=8)\end{array}$ \\
\hline \multicolumn{1}{c}{ Measurement } & 148 & 91 & 134 \\
$\begin{array}{l}\text { Plasma Na }{ }^{+}(\mathrm{mEq} / \mathrm{L}) \\
\text { Brain myo-inositol } \\
(\mathrm{mmol} / \mathrm{kg})\end{array}$ & $4.46 \pm 0.54$ & $0.54 \pm 0.12 \dagger$ & $0.87 \pm 0.10 \dagger$
\end{tabular}

* Treatment of animals (number in parentheses) and other procedures are given in "Materials and Methods." Plasma $\mathrm{Na}^{+}$levels are from Reference 11 .

$\dagger p<0.01$ versus control.

the sum of the measured amino acids and creatine in these same animals (11) was still reduced one-third or more. As a result rapid correction of chronic hyponatremia caused cellular dehydration and shrinkage of the brain (11).

Changes in the cerebral levels of myo-inositol (and amino acids) seen in chronic hyper- and hyponatremia are not merely a reflection of dehydration of the brain in one case, and edema in the other. Whereas the dry wt of the brain increased some 8 to $11 \%$ in chronically hypernatremic mice $(7,10)$, myo-inositol increased $43 \%$ and levels of most amino acids increased 20 to $90 \%(7,9,10)$. Furthermore, the $88 \%$ decrease of the myoinositol concentration in chronic hyponatremia was seen without any change in the brain water content (11).

\section{DISCUSSION}

During adaptation to chronically increased or decreased plasma $\mathrm{Na}^{+}$levels, levels of amino acids in the brains of young mice increased or decreased, respectively, to maintain osmotic equilibrium and to limit the loss or gain of water in brain (10, 11). The present data reveal similar paradoxic changes in the content of myo-inositol in the brains of these same animals. The 
reciprocal changes in the cerebral levels of myo-inositol in chronic hyper- and hyponatremia and their magnitude establish a role of myo-inositol in the maintenance of intracellular osmoregulation in mammalian brain comparable to that of amino acids and related nitrogenous compounds. For example, in the brains of chronically hypernatremic mice individual levels of six amino acids with a concentration of more than $1 \mathrm{mmol} / \mathrm{kg}$ (aspartate, glutamate, glutamine, GABA, glycine, taurine) increased 0.52 to $8.25 \mathrm{mmol} / \mathrm{kg}$, mean $2.32 \mathrm{mmol} / \mathrm{kg}$ (9). By comparison the myo-inositol content increased $2.07 \mathrm{mmol} / \mathrm{kg}$. In the chronically hyponatremic mice cerebral levels of these same amino acids decreased 0.78 to $5.82 \mathrm{mmol} / \mathrm{kg}$, mean 3.36 $\mathrm{mmol} / \mathrm{kg}(11)$, whereas the myo-inositol level fell $3.92 \mathrm{mmol} /$ $\mathrm{kg}$.

The mechanism of the adaptive changes in levels of amino acids and myo-inositol to maintain osmotic equilibrium across the cell membrane is unknown. $\mathrm{Na}^{+}$plays a critical role in the uptake of amino acids by brain and spinal cord (25-27) and in the uptake of myo-inositol in sciatic nerve (28) and in a neuroblastoma cell line (29). Thus, the reciprocal changes in the brain amino acid and myo-inositol contents in chronic hyper- and hyponatremia may be related to the respective increases or decreases of the plasma $\mathrm{Na}^{+}$concentration. Recently Trachtman et al. (30) found that taurine uptake was enhanced in synaptosomes isolated from the brains of hypernatremic rats when compared with control animals. The finding suggests that the cerebral transport of taurine (and possibly other osmolytes) in chronic hypernatremic dehydration reflects intrinsic alterations in cell metabolism or transmembrane uptake. Other explanations are possible.

Although generally not as great as with saline environments, adaptive increases of intracellular amino acids have been observed with sucrose in bacteria (3), toads (31), and mammals (1). Chronic water deprivation per se induced a 3-fold increase in the rate of uptake of amino acids in the rat pituitary neural lobe; plasma $\mathrm{Na}^{+}$levels were not given (32).

If similar osmoregulatory changes occur in man (the evolutionary data would suggest that they do), findings in the brains of chronically hyper- and hyponatremic animals may have clinical significance. The danger of precipitating seizures or coma following rapid correction of chronic hypernatremia in patients is well known. If the plasma $\mathrm{Na}^{+}$concentration was lowered to normal before the increased cerebral levels of amino acids, myoinositol (and other osmoles) were reduced to normal, then a reverse osmotic gradient (brain osmolality higher than blood) might be created causing an uptake of water from the extracellular space resulting in cerebral edema.

Overly rapid correction of chronic hyponatremia in man can induce cellular necrosis and demyelination in select symmetric regions of brain-the clinical pathologic syndrome of central pontine myelinolysis (33). In chronically hyponatremic mice adaptive reductions in the brain amino acid (11) and myoinositol contents (this study) permitted a normal brain water content despite extreme hyponatremia. Rapid treatment with saline restored the plasma $\mathrm{Na}^{+}$level to normal but had no significant effect on the depressed myo-inositol level. The brain amino acid content was still one-third less than normal (11). In consequence, rapid correction induced cerebral dehydration and shrinkage of the brain volume. How brain dehydration might cause or contribute to the development of central pontine myelinolysis after rapid correction of chronic hyponatremia in animals (34-37) and in man (33) is unknown.

Together with the previously published observations $(18,19)$ findings in this study establish a significant role of myo-inositol in the maintenance of intracellular osmoregulation in mammals. The changes in the brain levels of myo-inositol in these studies are remarkable. No condition other than chronic hypernatremia has been described that causes an increase in brain myo-inositol. The largest decrease in the level of brain myo-inositol previously reported was $70 \%$, after treatment of rats with lithium chloride and the centrally active cholinomimetic pilocarpine (38). This is to be compared with the $88 \%$ decrease we see in the brains of chronically hyponatremic mice. The effect of these procedures on brain phosphoinositide levels and on the inositol phosphate signalling system is presently under study.

Acknowledgments. The authors thank David B. McDougal, Jr. for his many helpful suggestions, and his critical review of the manuscript and Philip R. Dodge for his sustaining interest and encouragement.

\section{REFERENCES}

1. McDowell ME, Wolf AV, Steer A 1955 Osmotic volumes of distribution: Idiogenic changes in osmotic pressure associated with administration of hypertonic solutions. Am J Physiol 180:545-558

2. Duchateau G, Florkin M, Jeuniaux C 1959 Composante aminoacide des tissus, Chez les crustaces. 1. Composante amino-acide des muscles de Carcinus Maenas L. Lors du passage de l'eau de mer a l'eau saumatre et au cours de la mue. Arch Int Physiol Biochim 67:489-500

3. Measures JC 1975 Role of amino acids in osmoregulation of non-halophilic bacteria. Nature 257:398-400

4. Barnett NM, Naylor AW 1966 Amino acid and protein metabolism in Bermuda grass during water stress. Plant Physiol 41:1222-1230

5. Stewart GR, Lee JA 1974 The role of proline accumulation in halophytes. Planta (Berl) 120:279-289

6. Shank RP, Baxter CF 1973 Metabolism of glucose, amino acids, and some related metabolites in the brains of toads (Bufo Boreas) adapted to fresh water or hyperosmotic environments. $J$ Neurochem 21:301-313

7. Thurston JH, Hauhart RE, Jones EM, Ater JL 1975 Effects of salt and water loading on carbohydrate and energy metabolism and levels of selected amino acids in the brains of young mice. J Neurochem 24:953-957

8. Lockwood AH 1975 Acute and chronic hyperosmolality: Effects on cerebral amino acids and energy metabolism. Arch Neurol 32:62-64

9. Thurston JH, Hauhart RE, Dirgo JA 1980 Taurine: a role in osmotic regulation of mammalian brain and possible clinical significance. Life Sci 26:15611568

10. Thurston JH, Hauhart RE, Schulz DW 1983 Effect of chronic hypernatremic dehydration and rapid rehydration on brain carbohydrate, energy, and amino acid metabolism in weanling mice. J Neurochem 40:240-245

11. Thurston JH, Hauhart RE, Nelson JS 1987 Adaptive decreases in amino acids (taurine in particular), creatine, and electrolytes prevent cerebral edema in chronically hyponatremic mice: Rapid correction (experimental model of central pontine myelinolysis) causes dehydration and shrinkage of brain. Metab Br Dis 2:223-241

12. Matsushima O, Katayama H, Yamada K, Kado Y 1984 Occurrence of free Dalanine and alanine racemase activity in bivalve molluscs with special reference to intracellular osmoregulation. Mar Biol Lett 5:217-225

13. Awapara J 1962 Free amino acids in invertebrates: a comparative study of their distribution and metabolism. In: Holden JT (ed) Amino Acid Pools. Elsevier, New York, pp 158-175

14. Baxter CF, Ortiz CL 1966 Amino acids in the maintenance of osmotic equilibrium in brain tissue. Life Sci 5:2321-2329

15. Brown AD, Simpson JR 1972 Water relations of sugar-tolerant yeasts: the role of intracellular polyols. J Gen Microbiol 72:589-591

16. Borowitzka LJ, Brown AD 1974 The salt relations of marine and halophilic species of the unicellular green alga, Dunaliella. The role of glycerol as a compatible solute. Arch Microbiol 96:37-52

17. Nguyen A, Lamant A 1988 Pinitol and myo-inositol accumulation in waterstressed seedlings of maritime pine. Phytochemistry 27:3423-3427

18. Bagnasco S, Balaban R, Fales HM, Yang Y-M, Burg M 1986 Predominant osmotically active organic solutes in rat and rabbit renal medullas. $J$ Biol Chem 261:5872-5877

19. Lohr JW, McReynolds J, Grimaldi T, Acara M 1988 Effect of acute and chronic hypernatremia on myo-inositol and sorbitol concentration in rat brain and kidney. Life Sci 43:271-276

20. Lowry OH, Passonneau JV 1972 A Flexible System of Enzymatic Analysis. Academic Press, New York

21. Tukey JW 1953 The problem of multiple comparisons. Princeton University, Princeton, NJ. Cited by Kirk RE (ed) Procedures for the Behavioral Sciences. Brooks/Cole, Belmont, CA, pp 69-98

22. Stewart MA, Sherman WR, Kurien MM, Moonsammy GI, Wisgerhof M 1967 Polyol accumulations in nervous tissue of rats with experimental diabetes and galactosaemia. J Neurochem 14:1057-1066

23. Palmano KP, Whiting PH, Hawthorne JN 1977 Free and lipid myo-inositol in tissues from rats with acute and less severe streptozotocin-induced diabetes. Biochem J 167:229-235

24. MacGregor LC, Matschinsky FM 1984 An enzymatic fluorimetric assay for myo-inositol. Analytical Biochemistry 141:382-389

25. Lahiri S, Lajtha A 1964 Cerebral amino acid transport in vitro: I. Some requirements and properties of uptake. J Neurochem 11:77-86

26. Margolis RK, Lajtha A 1968 Ion dependence of amino acid uptake in brain slices. Biochim Biophys Acta 163:374-385 
27. Bennett JP Jr, Logan WJ, Snyder SH 1973 Amino acids as central nervous transmitters: the influence of ions, amino acid analogues and ontogeny on transport systems for L-glutamic and L-aspartic acids and glycine into centra nervous synaptosomes of the rat. J Neurochem 21:1533-1550

28. Greene DA, Lattimer SA 1982 Sodium- and energy-dependent uptake of myoinositol by rabbit peripheral nerve. J Clin Invest 70:1009-1018

29. Yorek MA, Dunlap JA, Ginsberg BH 1986 Myoinositol uptake by four cultured mammalian cell lines. Arch Biochem Biophys 246:801-807

30. Trachtman H, del Pizzo R, Futterweit S 1989 Taurine(T) transport is increased in synaptosomes isolated from brains of rats with hypernatremic dehydration (HD). Pediatr Res 25:349A

31. Baxter CF 1968 Intrinsic amino acid levels and the blood-brain barrier. In: Lajtha A, Ford D (eds) Progress in Brain Research, Vol 29. Elsevier, Amsterdam, pp 429-444

32. Gross PM, Blasberg RG, Fenstermacher JD, Patlak CS 1985 Rapid amino acid uptake in rat pituitary neural lobe during functional stimulation by chronic dehydration. J Cereb Blood Flow Metab 5:151-155

33. Sterns RH, Riggs JE, Schochet SS Jr 1986 Osmotic demyelination syndrome following correction of hyponatremia. N Engl J Med 314:1535-1542

34. Laureno R 1980 Experimental pontine and extrapontine myelinolysis. Trans Am Neurol Assoc 105:354-358

35. Kleinschmidt-DeMasters BK, Norenberg MD 1981 Rapid correction of hyponatremia causes demyelination: relation to central pontine myelinolysis. Science 211:1068-1070

36. Kleinschmidt-DeMasters BK, Norenberg MD 1982 Neuropathologic observations in electrolyte-induced myelinolysis in the rat. $\mathbf{J}$ Neuropathol Exp Neurol 41:67-80

37. Ayus JC, Krothapalli RK, Armstrong DL 1985 Rapid correction of severe hyponatremia in the rat: histologic changes in brain. Am J Physiol 248:F711F719

38. Sherman WR, Gish BG, Honchar MP, Munsell LY 1986 Effects of lithium on phosphoinositide metabolism in vivo. Fed Proc 45:2639-2646 